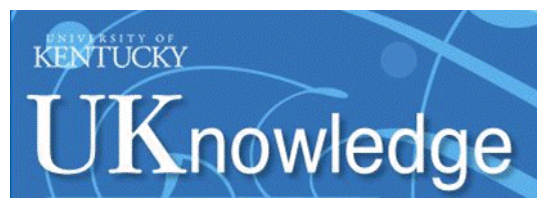

University of Kentucky

UKnowledge

$10-2001$

\title{
Labial Adhesion as a Complication of Primary Genital Herpes in Young Women
}

Hatim A. Omar

University of Kentucky, hatim.omar@uky.edu

Follow this and additional works at: https://uknowledge.uky.edu/pediatrics_facpub

Part of the Pediatrics Commons

Right click to open a feedback form in a new tab to let us know how this document benefits you.

\section{Repository Citation}

Omar, Hatim A., "Labial Adhesion as a Complication of Primary Genital Herpes in Young Women" (2001). Pediatrics Faculty Publications. 88.

https://uknowledge.uky.edu/pediatrics_facpub/88

This Article is brought to you for free and open access by the Pediatrics at UKnowledge. It has been accepted for inclusion in Pediatrics Faculty Publications by an authorized administrator of UKnowledge. For more information, please contact UKnowledge@lsv.uky.edu. 


\section{Labial Adhesion as a Complication of Primary Genital Herpes in Young Women}

Digital Object Identifier (DOI)

http://dx.doi.org/10.1515/IJAMH.2001.13.4.311

\section{Notes/Citation Information}

Published in International Journal of Adolescent Medicine and Health, v. 13, no. 4, p. 311-315.

(c) Freund Publishing House Ltd.

The copyright holder has granted permission for posting the article here. 


\title{
Labial adhesion as a complication of primary genital herpes in young women
}

\author{
Hatim A. Omar, MD \\ Section of Adolescent Medicine, Department of Pediatrics, University of Kentucky, \\ Lexington, Kentucky, Linited.Siates of America
}

\begin{abstract}
Genital herpes is a comtnon sexually transmitted distase in adolescents, It may be associated with significant morbidity if not diagnosed on time or not properly treated. The objective of this stuxly was to determine the incidence of labial sdhesion secondary to primary herpes in young women and the possible predisposing tactors far this complication. The method was analysis of clinical data regarding primary genital herpes in young women seen in an adolescent outpatient clinic at a university hospitat. Cases of primary getital herpes seen between December 1 st 1998 and November $30^{\text {tis }} 1999$ were included. A total of 34 female adolescents with age rarige $12 \sim 19$ years were diagnosed with primary genital herpes during this time period. Severn patients $(20.6 \%)$ were found to have severe labial sthesion at time of diagnosis. All seven patients were seen by other providets prior to their evaluation in the adolescent clinic, and four were correctly diagnosed. Alt seven patients were given antivinal therapy, but none were given local treatment. At time of diagnosis all seven patients had urinary retention for more than 24 hours and severe pain and discomfon. Three patients had diabetes mellitus (one of these was also pregnant), and one patient had asthma (on steroid therapy). The age range for these seven patients was $13-17$ years. Treatment with local anesthetics helped resolve the adhesion in five paticats, and sargical treatment was needed in the remaining two patients. It is concluded that labial adhesion is a severe complication of primary genital herpes in young women. Chronic medical conditions, incorrect diagnosis, and lack of topical ireatment may be associated with the development of this complication. Use of topical therapy should be an hutegral part of the comprehensive treatment for primary genital herpes in female adolescents to alleviate discomfost and prevent urinary retention and labial adhesion.
\end{abstract}

Keywords: Labial adhesion, genital herpes infoction, adolescents, United States

Correspondence: Hatim Omar, MD, Associate Proftessor, Director of Adolescent Medicine \& Yourag Parent programs, 1422, Kentuckicy Clinic, University of Kentucky, lexington, KX 40536-0284, United States. Tet: 859-323-6426 ext. 307, Fax. 859-257-7706, E-mail: Amomar2@pop.nky.edu

Submitted: February 5, 2001. Revised: Fetruary 27, 2001. Accogred: February 28, 2001

\section{INTRODUCTION}

According to the National Health and Nutrition Examination Survey (NHANES) (1), genital herpes is a very common sexually transmitted disease with seroprevalence of Herpes Simplex Virus 2 (HSV-2) of $21.7 \%$ in the general population of the United States in 1991. Most HSV -2 infections are acquired between $15-40$ years of age $(1,2)$, while HSV -1 is present in $20 \%$ of children $(<5$ years of age) and rises in finear fashion afterwards (2). Although most infections are mild or subclinical, severe complications can occur $(3,4)$ including the potential to facilitate Human immutuodeficiency Virus transmission (5-7). Many mild cases of genital herpes are not brought to medical attention or go unrecognized by clinicians ( 8 ).

Clinical manifestations of genital herpes may include ulcers, dysuria, urethral and vaginal discharge, vulvar irritation and possible fissures, in addition to classical vesiculopustular lesions $(3,4,9,10)$. Urinary retention may also occur due to local 
Table 1. Description of the patients with labial adheston. Sammary data showing the characteristics of patients with labial adhesion.

\begin{tabular}{ccccc}
\hline No. & Age & HSV & MODE OF TRANSMISSION & OTHER FACTORS \\
\hline 1 & 13 & 1 & nonsexual & IDDM \\
2 & 13 & 1 & oro-gerital & asthma \\
3 & 16 & 1,2 & intercourse & IDDM, Pregnancy \\
4 & 16 & 2 & Intercourse & None \\
5 & 14 & 2 & Intercourse & IDDM \\
6 & 17 & 2 & intercourse & None \\
7 & 15 & 2 & imercourse & None \\
\hline
\end{tabular}

symptoms of as a consequence of sacral radiculomyelopathy (11), and this may also cause sensation changes and constipation (11).

Over the last few years, we have encountered several patients each yoar with severe labial adhesion as a complication of primary gentital herpes. Most of these patientis also had urinary retention for various lenghis of time. Searching the literature revealed a lack of information regarding this complication, which was only rnentioned in wssociation with a photograph of labial adhesiot (11). This study attempted to identify the incidence of labial adtuesion ht association with primary gentital herpes, and looked for possible factors assoctated with this condition in young women. The effects of local therapy on labial adthesions were also studied.

\section{METHODS}

Clinical data regarding genital herpes in young women in an adolescent clinuc outpatient setting was analyzed. Cases of primary genitul herpes diagnosed between December $1^{\text {st }}, 1998$ through November 30 , 1999 were included. During this time period any patient with significarat complications because of primary genital herpes had herpes culture, serologic studtes, or both to contirm diagnosis and identify the type of virus. In patients with a cleas clinical picture and no serious compin- cations, diagnosis was verified with trank smear, viral culture or serology.

\section{RESULTS}

In the twelve months included in this study, 34 femalle adolescents with age range 12-19 years were diagnosed with primary genital herpes. Seven patierts $(20.6 \%)$ had a severe labial athesion at the time of diagnosis (Figs. 1 a and $b$ ), and all seven patients were seen by mimary care providers or an emergency room physicians prior to visiting the adolescent clinic. Four of these were correctly diagnosed with herpes curing their mitial visit, and the other three had "uncertain Dx."

All sever patients were started on antiviral therapy prior to their visit to the adolescent clinic, but none were given local therapy. When evaluated in the adolescent clinic, all seven patients had urnary retention for at least 24 hours severe pain and discomfort, and no defecation for at least two days. THree patients were also known diabetics fone of them was also found to be pregnant) and one patient was on steroid therapy for asthma (Table 1). HSV 2 was Identified in four patients, and two bad HSV 1. The last patient had both HSV 1 and HSV 2 (Table 1). Based on thorough history, mode of infection transmission was found to be via intercourse in most cases (Table 1). Mean age of this group was 15.9 with standard deviation of 1.6. The other 27 patients had a 


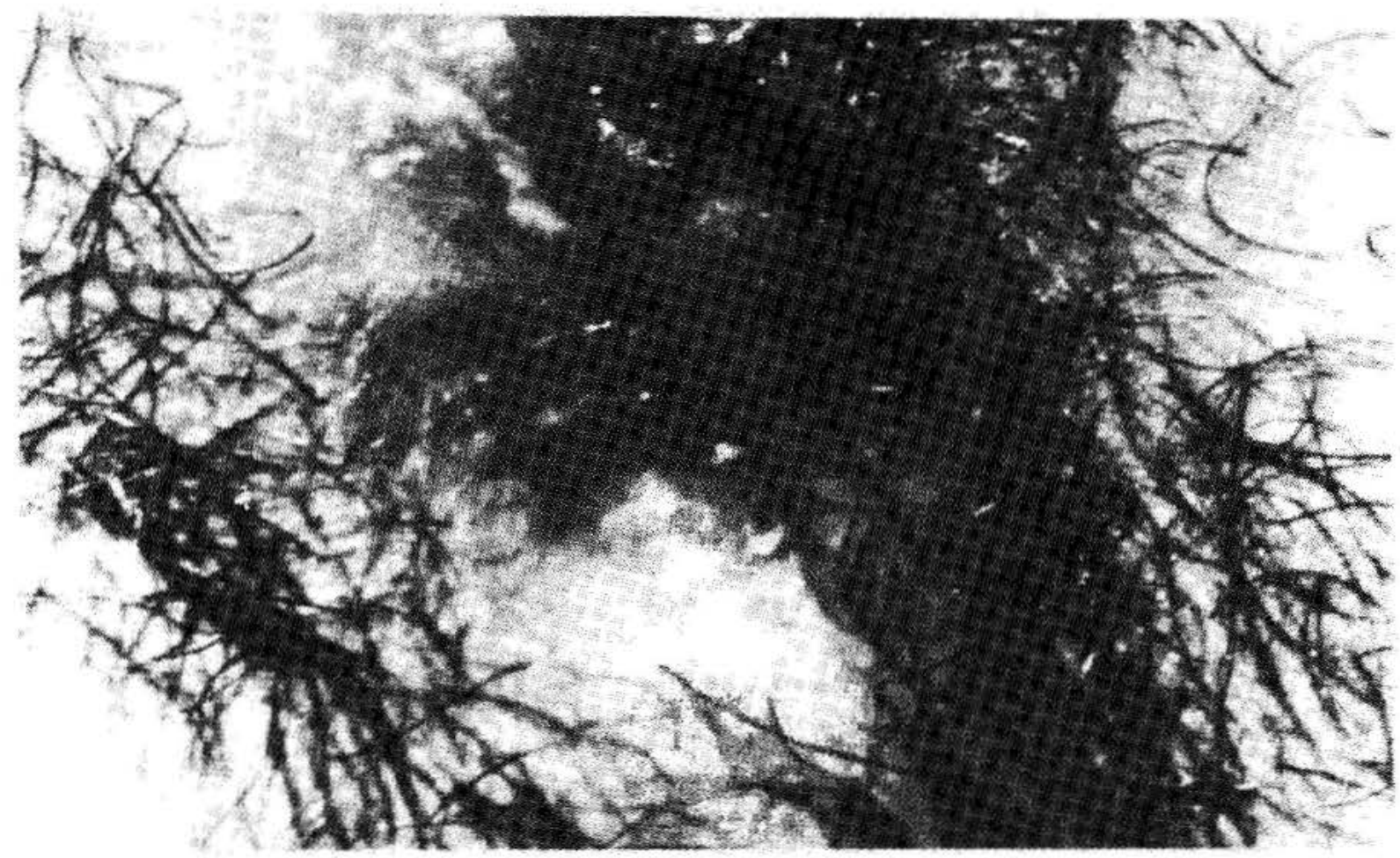

(a)

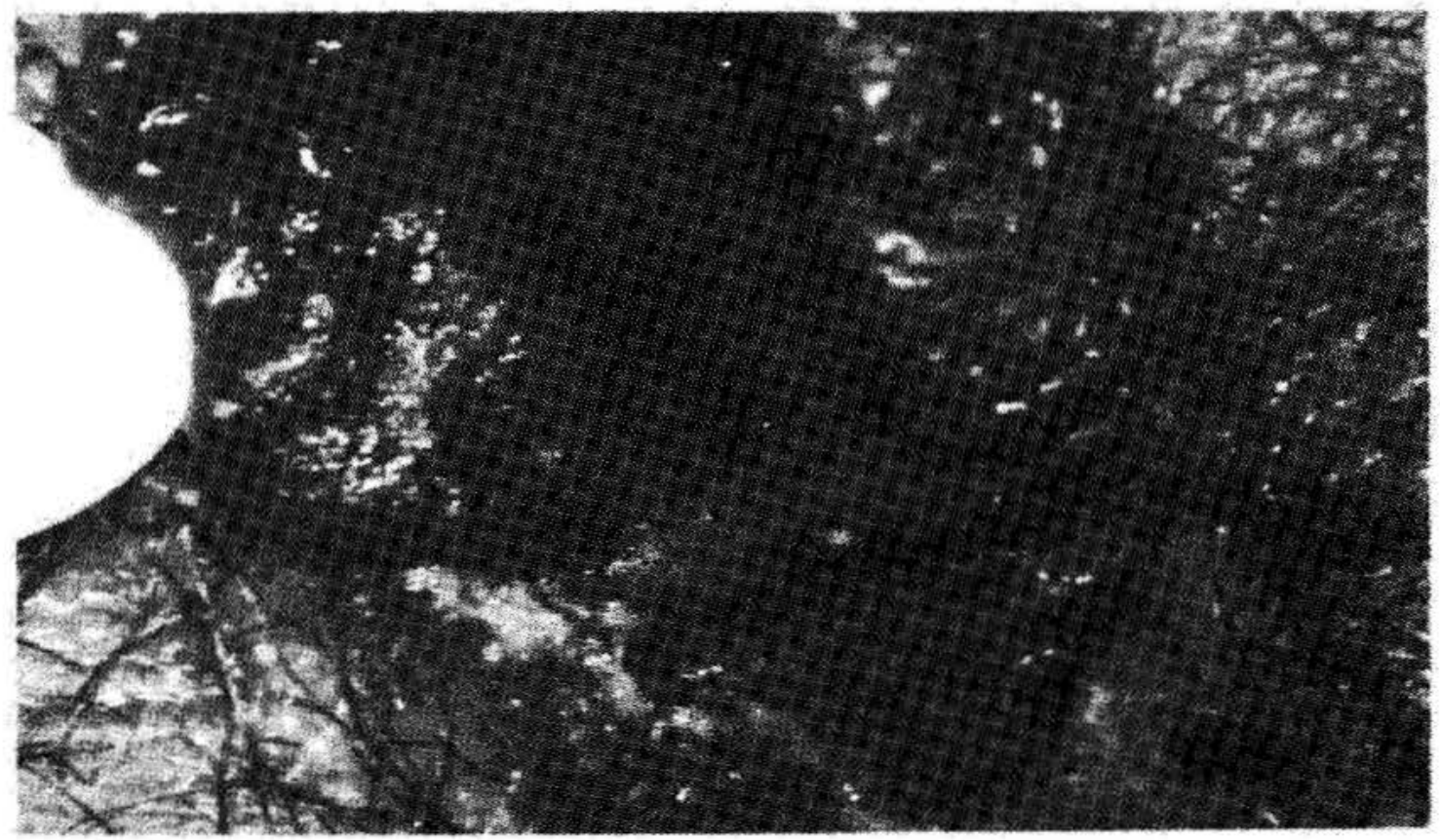

(b)

Figs. 1a and b: Colposcopic photograph of a 13 year-oid patient showing complete labial adhesion. 
mean age of 16 with standard deviation of 1.9. Fifteen of the 27 patients in this grous were initially diagnosed in the alolescent clinic, and 12 were referrals. None of these pattents had any other medical conditions, and HSV 2 was identified in 18 white HSV 1 was found in two patients. The remaining seven patients had only trank smears with no serology or culture. All patients with genital herpes seen in the adolescent chinic are routinly given local treatment as described below.

All seven patients with labial adnesions were given a mixture of $2 \%$ viscous lidocaine (50\%). Diphenhydramine $(25 \%)$, and an antiacid such as Maatox (25\%) to apply locally every rwo hours. Patients ware instructed to utilize warm water in a bathtub for urination and defecation. In five of theste putients the adtesions resolved within at week, while the other two patients required ruecharical separation under anesthesia becasise of persistence of the adhesions and continuing difticulty during urination.

\section{DISCLSSION}

Based on this study, Labial adhesion appears to be a relatively commot, severe complin cation of primary genital herpes in young wornen despite the lack of attertion to is in literature. in this study the very youmg age, chronic rtedical conditions, preguancy, and lack of local therapy were associated with development of this condition. The small number included here does not allow any major conclusions in regards to this association, and further studies are needed to verify that. At this point there is no knowledge in regards to why some patients develop this problem while others do not However, the fact that wone of our heathy patients had it suggests that the above mentioned factors are associated with this complication.

The associated urinasy retention may aggravate the condition of these patients and could lead to renal failure if not resolved gnuickly, especially in diabetic patients. None of the patients diagnosed initially in our clinic and given local therapy, as mentioned above, in adfition to the antiviral regimen, developed alhesions. This and the excellent response to local therapy in five of the sever patients siggeest that if is of utmost importance to provide local treatment to these patients at time of diagnosis.

Considering the lack of any studies on labtal adhesions as a complication to primary gental herpes, it may be useful for primary care providers to be aware of this complication, and more research is needed to further our understandiug of this problem.

\section{CONCLUSION}

Labial adhesion is a serious complication of printary gewatal herves in young women. especially those with adverse medical condit ions. Local therapy with topical anesthetics should be part of the comprehensive manage ment of primary genital herpes in young women to allevate pain and help prevent wrinary retention and labial adhesion.

\section{ACKNOWLEDGEMENTS}

This strudy was presented in part at the $14^{\text {th }}$ Ammal Meeting of the North American Society of Pediatric and Adolescent Gythecology, Axlanta, GA, April 2000.

\section{REIERENCES}

1. Flemting DT, McQuillan GM, Johnson RE, er al. Herpes simplex vinus type 2 in the United States, 1976 to $1994 . \mathrm{N}$ Fing I Med. 1997;337:1105-11.

2. Johnson $\mathrm{RE}$, Nahmias $\mathrm{AJ}$, Magder LS, et al, A seroepidemiology survey of the prevalence of herpes simplex virus type 2 infection in the United States. N Eng J Med. 1989;321:7-12.

3. Langenterg ACM, Corey 1. Ashley $R L$, al. A prospective study of new infections with HSV -1 and HSV-2.N Eng J Med. 1999;341:1532-538.

4. Corey $L$, Adams $\mathrm{HG}_{3}$ Brown $\mathrm{ZA}$, 
Holmes KK. Genital herpes simplex virus infection:clínical manifestations, course and complications. Ann Intern Med. $1983 ; 98: 958-72$.

5. Greenblatt RM, Lukehart $\$ \mathrm{~A}$, Plummer FA, et al. Cenital ulceration as a risk factor for human immunodefictency virus infection. AIDS, 1988;2:47\%50.

6. Holmberg $\$$, Stewart JA, Gerger $A R$, et al. Herpes simplex virus infection as a risk factor for ITV infection. IAMA. $1988,259: 1048-51$.

7. Hook $\mathrm{E}$, Comnon RO, Nohmias $\mathrm{AJ}$. Herpes simplex virus infection as a risk factor for human immunodefictency virus infection in heterosexuals. I Trfect Dis. 1992;165.251-5.

8. Corey L, Handsfield HH, Genital herp- es and poblic health: addressing a global problem. JAMA. 2000;283:791-4.

9. Corey 1, Wald A, Genital herpes. In: Holmes KK, Mard PA, Sparling PF, eds. Sexually Transmitted Diseases. $3^{\text {ra }}$ ed. New York, NY: McGraw Hill; $19992285-312$

10. Koutsky L, Stevens CE, Holmes KK, et al. Under diagnosis of genital herpes by current clinical and viral isolation procedures. N Fing I Med. 1992; $326: 1533-9$.

11. Wisdom $A$, Hawkins DA. Herpes genitalis, In: Wisdom A, Hawkins DA, eds. Diagnosis in color: Sexually Transmitted Diseases, $2^{\text {xt }}$ ed. London, Mosby-Wolfe; 1997; 167-82.

\title{
BITS N PIECES
}

\section{Alcohol use among Australian secondary students in 1996}

\begin{abstract}
This research estimates the prevalence of alcohol use among Australian secondary students in 1996 and examines trends th alcohol prevalence over a 12 . year period. A national rancomly selected sepresentative sample of 434 secondary schools participated in the 1996 study. Eighty students were selected randomly from each school and completed a questitorataire anonymowsly. Cument drinking (drinking alcohol in the week before the swrvey) increased with age from $17 \%$ of boys and $10 \%$ of firis aged 12 to $56 \%$ of boys and $50 \%$ of giris aged 17. Comparisons with data collected by similar surveys in 1984, 1987, 1990 and 1993 showed that while fewer 12-15-year-oids were carrent drinkers in 1996 than it 1984 or 1987 , the 1996 proportion was no different from the 1993 proportion. In 1996, there were more hazardous drinkers among male current drinkers aged 12 is than in any other survey period. Among 16- and 17-year olds, there were more current drimkers in 1996 than in 1993 of 1990 , and more male and fernale current drinkers were drinking at hazadous levels in 1996 than in 1987 and 1990. Extrapolating from the 1996 findings, nearly 424000 stadents aged $12-17$ years were current drinkers.
\end{abstract}

White VM, Hill DI, Letcher TR. Drug Alcohol Rev 2000;19;371-9. 


\section{BITS 'N PIECES}

Increasing paramedtes ${ }^{*}$ comfort and knowledge about children with special health care needs

Abstract: This study evaluated a continuing education program for paramedics about children with special health care needs (CSHCN). Pretraining posttraining, and followatu surveys containing two scales (comfort with CSHCN management skills and comfort with Pediatric Advanced Life Support [PALS] skills) were administered. Objective measures of knowledge were obtained from prem and postraining tests. Differences in average scores were assessed using t-tests. Response rates for paranedics completing the program ranged from $94 \%$ for the postraining survey, $81 \%$ for the initial confort survey, $56 \%$ for the knowledge pretest, and $56 \%$ for the follow-up survey. PALS comfort scores were significantly higher than CSHCN comfort scores both before and after training. both $\mathrm{P}<.01$. Postraining strveys showed an uncrease in CSHCN comfort, $\mathrm{P}<$ 01. The follow-up surveys showed a signiticant decline in CSHCN comfort, P w 05. Seores on the tests showed a similar patterm, with a significant increase in knowledge from pre- to posttraining $(\beta$ we 02 ) and a significant decrease in knowledge from posttraining to follow-up $(P<, 01)$. Comfort was singificantly higher for standard podiatric skills than for specialized management skills. Completion of the self -study program was associated with an increase in comfort and knowledge, but there was some decay over time.

Spaite DW, Katherine $\boldsymbol{J}$, Karriker $\mathbf{K} J$, Seng M, Conroy C, Battaglia N, Tibbitts M, Melslin HW, Salik RM, Valenzuela TD. An J Emerg Med $2000 ; 18: 747.52$. 